\title{
Measurement of Growth, Yield, Biomass and Heavy Metals Accumulation in Red Spinach Grown under Industrial Effluents
}

\author{
Mohammad Saiful Islam ${ }^{1}$, Md. Sirajul Islam ${ }^{2 *}$, Tanmoy Roy Tusher ${ }^{3}$, Mausumi Rehnuma ${ }^{4}$, \\ Md. Humayun Kabir ${ }^{5}$ \\ 1,2,3,4,5 Department of Environmental Science and Resource Management, Mawlana Bhashani Science and \\ Technology University, Tangail-1902, Bangladesh \\ *Corresponding Author (Email: islammstazu@yahoo.com)
}

How to cite this paper: Islam, M.S., Islam, M.S., Tusher, T.R., Rehnuma, M. and Kabir, M.H. (2019). Measurement of Growth, Yield, Biomass and Heavy Metals Accumulation in Red Spinach Grown under Industrial Effluents. Grassroots Journal of Natural Resources, 2(4): 26-37. Doi: https://doi.org/10.33002/nr2581.6853.02043

Received: 24 October 2019

Reviewed: 31 October 2019

Provisionally Accepted: 10 November 2019

Revised: 17 November 2019

Finally Accepted: 30 November 2019

Published: 31 December 2019

Copyright (C) 2019 by author(s) and

The Grassroots Institute.

This work is licensed under the Creative Commons Attribution International License (CC BY 4.0). http://creativecommons.org/licenses/by/4.0/
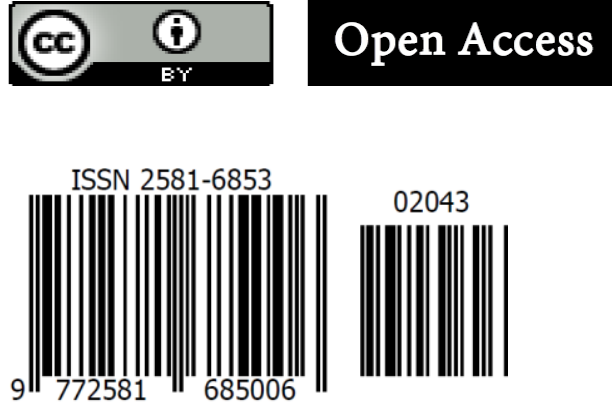

\begin{abstract}
The study was conducted to measure the growth, yield, biomass and heavy metal accumulation in red spinach (Amaranthus dubius) irrigated with treated and untreated industrial effluents, and groundwater. A total of twelve experimental plots, with three treatments (treated, untreated industrial effluents and groundwater) and four replications, were prepared inside the Jananeta Abdul Mannan Hall of Mawlana Bhashani Science and Technology University campus, where red spinach was cultivated and irrigated with 2.5 liter treated, untreated industrial effluents and groundwater in each plot. The content of $\mathrm{Zn}$ as 193.28, $182.83,136.55$ and $210.07 \mathrm{ppm}, \mathrm{Cd}$ as $0.77,0.87,0.93$ and 1.03 ppm, $\mathrm{Cu}$ as 47.32, 48.93, 57.29 and $73.58 \mathrm{ppm}$, were recorded in initial soil, soil irrigated with groundwater, treated and untreated industrial effluents, respectively. The content of $\mathrm{Zn}$ as 0.00, 0.00 and $0.07 \mathrm{ppm}, \mathrm{Cd}$ as 0.004, 0.006 and $0.011 \mathrm{ppm}$, and $\mathrm{Cu}$ as 0.00, 0.02 and $0.68 \mathrm{ppm}$, were recorded in groundwater, treated and untreated industrial effluent, respectively. The content of $\mathrm{Zn}$ as 61.64, 65.30 and $67.67 \mathrm{ppm}, \mathrm{Cd}$ as $0.33,0.52$ and $0.57 \mathrm{ppm}, \mathrm{Cu}$ as 5.73, 7.79 and $7.95 \mathrm{ppm}$, were investigated from red spinach plant irrigated with groundwater, treated and untreated industrial effluent, respectively. The levels of cadmium in the red spinach were much higher than that of WHO/ FAO recommended level.
\end{abstract}

Keywords

Red spinach; Irrigation; Industrial effluents; Heavy metal accumulation 
Doi: https://doi.org/10.33002/nr2581.6853.02043

\section{Introduction}

Wastewater disposal is becoming a problem in developing countries as large quantities of municipal wastes and industrial effluents are being produced due to increased urbanization and industrialization, respectively (Alloway, 1995). In Bangladesh, wastewaters from almost all the industries are being discharged untreated either on land or into the watercourses. Whatever the treatment facilities exist, are not operating properly. Resultantly, wastewater pollutes the water resources and ultimately the agriculture land (Arjun et al., 2013). Effluents from industries, which are normally considered as the main industrial pollutants containing suspended solids, toxic chemicals, oils, greases, dyes, radioactive wastes and thermal pollutants are discharged into the nearby water bodies. It makes the water unsuitable for fisheries, irrigation or for other uses. It has been found that the growth, yield and soil health get reduced when the farmers use the effluents for irrigation of the cultivated land (Nandy and Kaul, 1994). Heavy metals are being released from various sectors of industries such as textile, electroplating, fertilizer, leather, paint, pesticide, pharmaceuticals, pulp and paper, mining, oil refinery etc. The accumulation of these heavy metals in plants causes physiological and biochemical changes (Singh and Singh, 1981; Fisher, Jones and Nelson, 1981).

With the industrial development, the production and emission of heavy metals have increased. Heavy metal pollution poses a great threat to the environment and human health worldwide due to the persistent nature and toxicity of heavy metals and their accumulation in the food chain (Bahadir et al., 2007). High concentrations of heavy metals in soil can negatively affect crop growth, as these metals interfere the metabolic functions in plants, including physiological and biochemical processes, photosynthesis, respiration and germination. Soil contamination with heavy metals may also cause changes in the composition of soil microbial community, adversely affecting soil characteristics (Pagotto et al., 2001). Plants do not readily absorb large amount of heavy metals, and the amount they absorb depends on species and variety of plant, the chemical composition of the soil, the concentration of heavy metals and the soil $\mathrm{pH}$ among other factors. Intake by vegetables is an important path of heavy metals toxicity to human being. Dietary intake of heavy metals through contaminated vegetables may lead to various chronic diseases. The bio-toxic effect of heavy metals depends upon the concentration and oxidation state of heavy metals, kind of sources and mode of deposition (Fernandes and Henriques, 1991).

The toxic effects of heavy metals in different crops may differ significantly (Komarek et al., 2008). Many species of plants have been successful in absorbing contaminants such as lead, cadmium, chromium, arsenic, and various radio nuclides from soils. Toxic metals build up in biological systems and become a significant health hazard (Diskshith and Diwan, 2003). Thus, the study was designed to investigate the growth and yield of red spinach (Amaranthus dubius) irrigated with groundwater, treated and untreated industrial effluents, and to assess the accumulation of heavy metals $(\mathrm{Zn}, \mathrm{Cd}$ and $\mathrm{Cu})$ in red spinach under same conditions.

\section{Materials and Methods}

The study was conducted at the campus of Mawlana Bhashani Science and Technology University (MBSTU), Tangail. The leafy vegetables red spinach (Amaranthus dubius) was cultivated in the experimental plots inside the Jananeta Abdul Mannan Hall (MAMH) of MBSTU campus. 


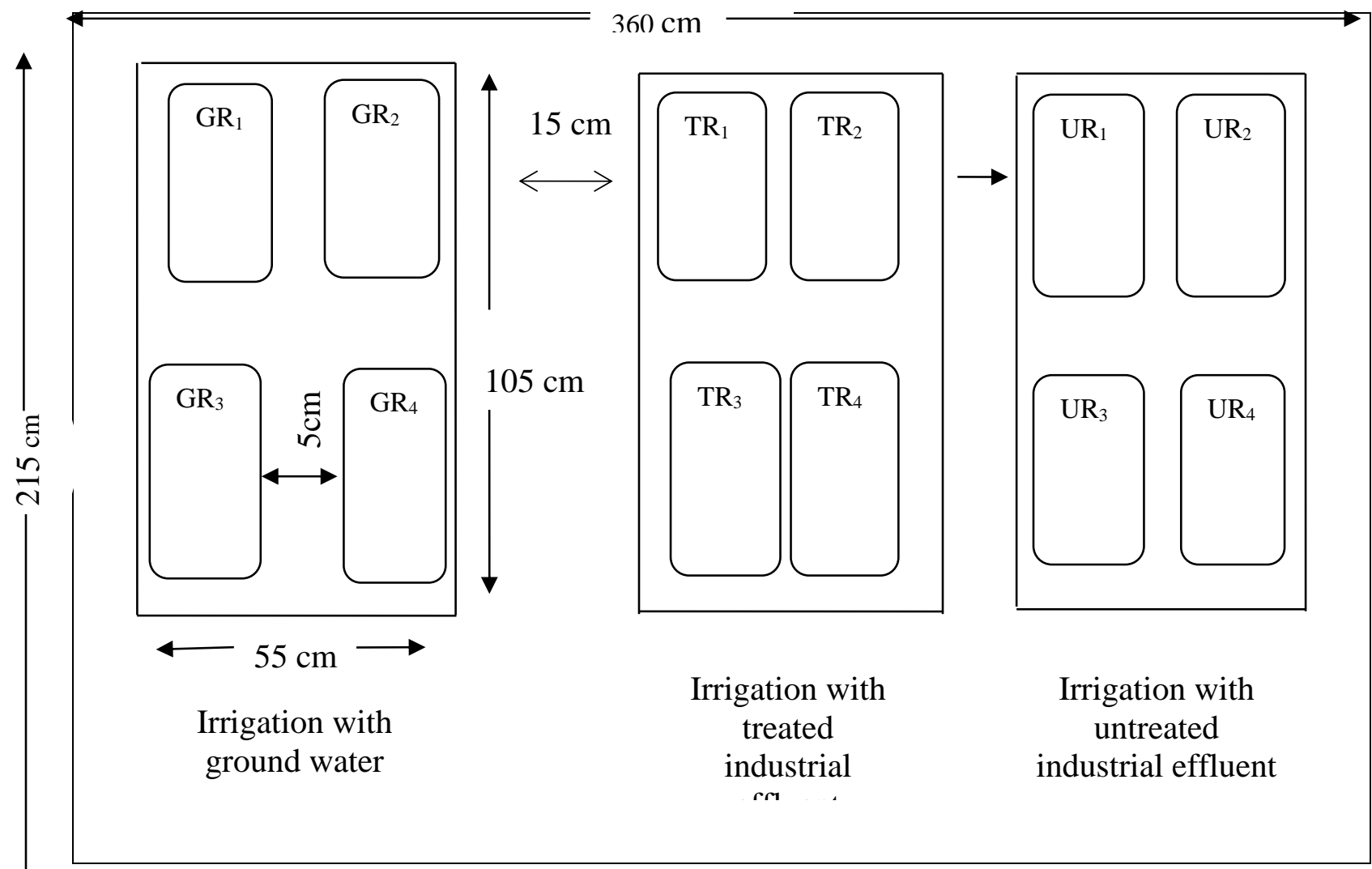

Figure 1: Layout of experimental plots for red spinach (Amaranthus dubius) cultivation

The experimental plots were prepared on 2 January 2016. The land was ploughed several times to obtain a good condition. Then the land was leveled, and the weeds, stubble and crop residues were removed. The land was finally prepared for planting the seeds of red spinach. The complete design of the experimental plots is shown in Figure 1. The study was conducted with four replications for three treatments: treated, untreated industrial effluent and ground water. Treated and untreated effluents were collected from Alauddin Textile Mills (ATM) Limited at Tarutia in Tangail. The treated effluent means the effluent which was treated with effluent treatment plant (ETP) operated by the authority of ATM Limited. Groundwater was collected from the tap of Jananeta Abdul Mannan Hall (JAMH) of MBSTU campus. The four replications for treated effluent were denoted as $\mathrm{TR}_{1}, \mathrm{TR}_{2}, \mathrm{TR}_{3}$ and $\mathrm{TR}_{4}$ whereas $\mathrm{UR}_{1}, \mathrm{UR}_{2}, \mathrm{UR}_{3}$ and $\mathrm{UR}_{4}$ for untreated effluents, and $\mathrm{GR}_{1}, \mathrm{GR}_{2}$, $\mathrm{GR}_{3}$ and $\mathrm{GR}_{4}$ for groundwater replications. The seeds of red spinach were collected from the local seed shop at Park Bazar in Tangail town. The seeds were sowed on $5^{\text {th }}$ January 2016. Germination of seeds started from $3^{\text {rd }}$ day of sowing. On the $5^{\text {th }}$ day maximum seeds were germinated. When the seedlings established in the beds it was always kept under careful observation. Weeding was done to keep the plots free from weeds, easy aeration of soil, which ultimately ensured better growth and development. Thinning and first weeding was done at 10 days after sowing (DAS) and again done when necessary. The red spinach growth was very luxuriant in two treatments viz plots receiving 2.5 liter treated effluent and 2.5 liter untreated effluent. However inadequate growth was observed in case of groundwater. To evaluate yield, two harvesting were done at different growth stages. First harvesting was done at 25 days after sowing seeds on 30 January 2016 and second harvesting was done at 45 days after sowing seeds on $20^{\text {th }}$ February 2016. Different yield 
contributing data were recorded from the mean of four harvested plants which were selected at random of each unit plot of every harvesting stage.

Sample collection: Plot soil samples were collected in two phases. Firstly, before sowing the seeds, a composite soil sample was collected to know the initial heavy metal concentration ( $\mathrm{Zn}, \mathrm{Cd}$ and $\mathrm{Cu}$ ). Secondly, after the harvesting of plant samples, three composite soil samples from each treatment were collected to know the irrigational effects of different treatments on soil and investigate heavy metals concentration. Heavy metals concentration in collected treated effluent, untreated effluent and ground water were also investigated. Plant samples were also collected in two phases. In $25^{\text {th }}$ and $45^{\text {th }}$ day (DAS: days after sowing), plant samples were collected to assess the irrigational effects of different treatments on the physical properties (growth and yield) and heavy metals concentration in red spinach.

Sample analysis: Soil, water/ effluents, and plant samples were analyzed in Bangladesh Institute of Nuclear Agriculture (BINA), and Bangladesh Agriculture University (BAU), Mymensingh for determining the concentration of heavy metals such as $\mathrm{Zn}, \mathrm{Cu}$ and $\mathrm{Cd}$. Plant samples were analyzed with two categories: i) determined the physical properties such as number of leaves per plant, length of leaf, breadth of leaf, root length, base diameter of plant, yield per plot, and yield per hectare of red spinach in the field, and ii) laboratory based analysis for measurement of heavy metal concentrations by Atomic Absorption Spectrophotometer (AAS) in BINA. The moisture content of red spinach plant obtained from the following equation:

Moisture content $(\%)=\frac{\text { Green weight-Oven dry weight }}{\text { Green weight }} \times 100$

Statistical analysis: The collected data were compiled and tabulated in proper form and were subjected to statistical analysis. The Microsoft Office Excel software was used to present and interpret the collected data.

\section{Results and Discussion}

Different irrigation sources had significant effect on growth and yield of red spinach plant. The variation of leaves length of red spinach was observed in different plot due to the irrigation by industrial effluent and ground water at 25 and 45 DAS (days after sowing). The maximum leave length $\left(5 \mathrm{~cm}\right.$ ) was observed in $\mathrm{UR}_{3}$ (43290 liter/ ha untreated effluent) treatment and lowest leave length $(2.25 \mathrm{~cm})$ was observed in $\mathrm{GR}_{2}$ (43290 liter /ha ground water) treatment at 25 DAS. At 45 DAS the maximum leave length $(8.5 \mathrm{~cm})$ obtained from $\mathrm{UR}_{2}$ (43290 liter/ ha untreated effluent) and the lowest leave length $\left(4.25 \mathrm{~cm}\right.$ ) observed from $\mathrm{GR}_{4}$ (43290 liter/ ha groundwater) treatment (Table 1). It was observed that the irrigation by untreated effluent showed the best result than that of other treatment on cultivation of red spinach. Groundwater also indicated the sufficient production of red spinach.

At 25 DAS, the maximum number of leaves per plant (7) was found from $\mathrm{UR}_{2}$ and minimum number of leaves per plant (4) was found from $\mathrm{GR}_{3}$. At 45 DAS, the maximum number of leaves per plant (15) was found from $\mathrm{UR}_{2}$, and the minimum number of leaves per plant (8) was obtained from GR 4 (Table 1). It was revealed that with the increase of untreated effluent, number of leaves per plant 
increase up to a certain level than decrease slowly. The maximum number of leaves per plant was recorded for high level irrigation by untreated effluent because untreated effluent ensures favorable condition for the growth of red spinach. It was revealed that optimum level of treated and untreated effluent ensured the maximum number of leaves per plant. Mohiuddin et al. (2016) found the average leaf number of five plants per pot irrigated with polluted river water was ranged from 4 to 9.4 with an average of 6.8. Naz, Anjum and S. Akhtar (2016) found total number of leaves per spinach plant irrigated with canal, tube well and sewage water were 21.56, 20.58 and 24.86, respectively.

Variation was recorded on leaf breadth per plant of red spinach due to irrigation by different types of water at 25 and 45 DAS. At 25 DAS, the maximum leaf breadth per plant $(3.25 \mathrm{~cm})$ was found from $\mathrm{UR}_{2}$ and minimum leaf breadth per plant $(2.10 \mathrm{~cm})$ was found from $\mathrm{GR}_{3}$. At $45 \mathrm{DAS}$, the maximum leaf breadth per plant $(5.25 \mathrm{~cm})$ was found from $\mathrm{UR}_{2}$, and the minimum leaf breadth per plant $(2.75$ $\mathrm{cm}$ ) was obtained from $\mathrm{GR}_{1}$ (Table 1).

Table 1: Effect of industrial effluent and groundwater on leaves length, number of leaves per plant, leaf breadth and base diameter of red spinach

\begin{tabular}{cccccccccc}
\hline \multirow{2}{*}{$\begin{array}{c}\text { Water/ } \\
\text { effluent }\end{array}$} & Treatment & \multicolumn{2}{c}{$\begin{array}{c}\text { Length of leaves } \\
(\mathrm{cm})\end{array}$} & \multicolumn{2}{c}{ Number of leaves } & $\begin{array}{c}\text { Breadth of leaves } \\
(\mathrm{cm})\end{array}$ & $\begin{array}{c}\text { Base diameter of } \\
\text { spinach }(\mathrm{cm})\end{array}$ \\
\cline { 2 - 10 } Ground & $\mathrm{GR}_{1}$ & 3.00 & 5.00 & 5 & 10 & 2.50 & 2.75 & 0.40 & 1.00 \\
water & $\mathrm{GR}_{2}$ & 2.25 & 4.75 & 5 & 11 & 2.50 & 3.00 & 0.50 & 0.90 \\
& $\mathrm{GR}_{3}$ & 3.00 & 5.00 & 4 & 9 & 2.10 & 3.00 & 0.80 & 1.10 \\
& $\mathrm{GR}_{4}$ & 3.25 & 5.50 & 6 & 8 & 2.25 & 3.25 & 0.75 & 1.00 \\
\hline \multirow{2}{*}{ Treated } & $\mathrm{TR}_{1}$ & 3.50 & 5.50 & 5 & 10 & 3.00 & 4.00 & 0.50 & 1.00 \\
effluent & $\mathrm{TR}_{2}$ & 3.75 & 5.00 & 6 & 12 & 3.00 & 4.00 & 0.50 & 1.10 \\
& $\mathrm{TR}_{3}$ & 3.00 & 6.50 & 5 & 12 & 3.10 & 4.25 & 0.60 & 1.10 \\
& $\mathrm{TR}_{4}$ & 4.25 & 4.75 & 6 & 10 & 3.20 & 4.20 & 0.75 & 1.10 \\
\hline \multirow{2}{*}{ Untreated } & $\mathrm{UR}_{1}$ & 4.75 & 8.00 & 4 & 12 & 3.00 & 4.50 & 0.60 & 1.20 \\
effluentyyyyyyyy & $\mathrm{UR}_{2}$ & 4.00 & 8.50 & 7 & 15 & 3.25 & 5.25 & 0.60 & 1.10 \\
& $\mathrm{UR}_{3}$ & 5.00 & 7.50 & 6 & 11 & 3.00 & 4.25 & 0.70 & 1.50 \\
& $\mathrm{UR}_{4}$ & 3.75 & 8.25 & 6 & 12 & 3.00 & 4.50 & 0.90 & 1.10 \\
\hline
\end{tabular}

Note: $\mathrm{GR}_{1}, \mathrm{GR}_{2}, \mathrm{GR}_{3}, \mathrm{GR}_{4}$ indicate four plots irrigated with groundwater, $\mathrm{TR}_{1}, \mathrm{TR}_{2}, \mathrm{TR}_{3}, \mathrm{TR}_{4}$ indicate four plots irrigated with industrial treated effluents, and $\mathrm{UR}_{1}, \mathrm{UR}_{2}, \mathrm{UR}_{3}, \mathrm{UR}_{4}$ indicate four plots irrigated with industrial untreated effluents. DAS = days after sowing.

Base diameter per plant of red spinach varied due to irrigation by different types of water at 25 and 45 DAS. At 25 DAS, the maximum base diameter per plant $(0.9 \mathrm{~cm})$ was found from $\mathrm{UR}_{3}$ and minimum base diameter per plant $(0.4 \mathrm{~cm})$ was found from $\mathrm{GR}_{1}$. At $45 \mathrm{DAS}$, the maximum base diameter per plant $(1.5 \mathrm{~cm})$ was found from $\mathrm{UR}_{3}$, and the minimum base diameter per plant $(0.9 \mathrm{~cm})$ was obtained from $\mathrm{GR}_{2}$ (Table 1). Variation in number of red spinach plant per plot recorded due to irrigation by different types of water at 25 and 45 DAS. The highest number of plant (170) was recorded from $\mathrm{UR}_{1}$. The second highest number of plant (165) was observed from $\mathrm{UR}_{3}$. The minimum number of plant (116) was observed from $\mathrm{GR}_{2}$ (Figure 2). Mohiuddin et al. (2016) observed in their study that total number of red amaranth plants irrigated with polluted river water varied from 16 to 45 with an average of 30 . They also recorded the plant heights of the red amaranth 
plants irrigated with polluted river water were ranging from 10.7 to $24 \mathrm{~cm}$ and the average height of the control plants were $22.2 \mathrm{~cm}$.

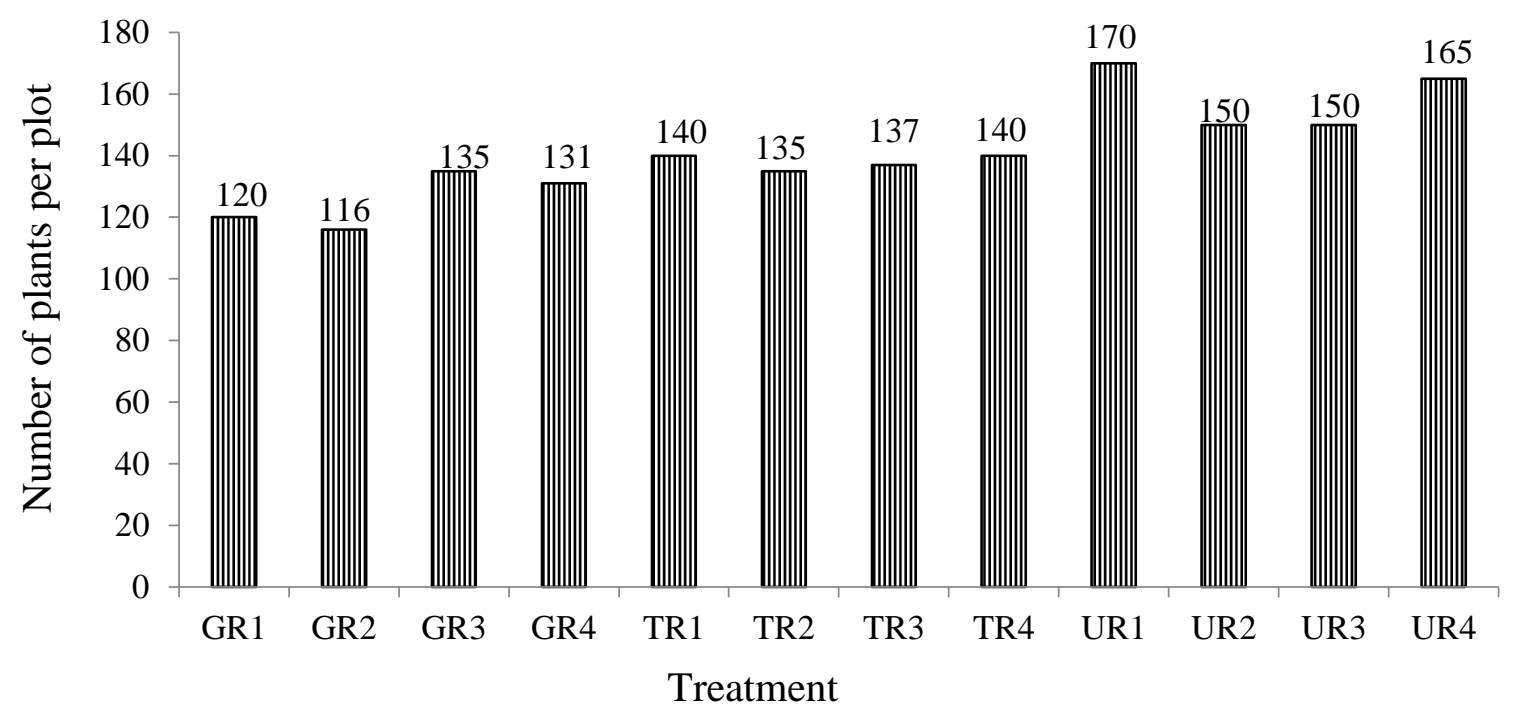

Figure 2: Effect of industrial effluent and groundwater on the growth and number of plants

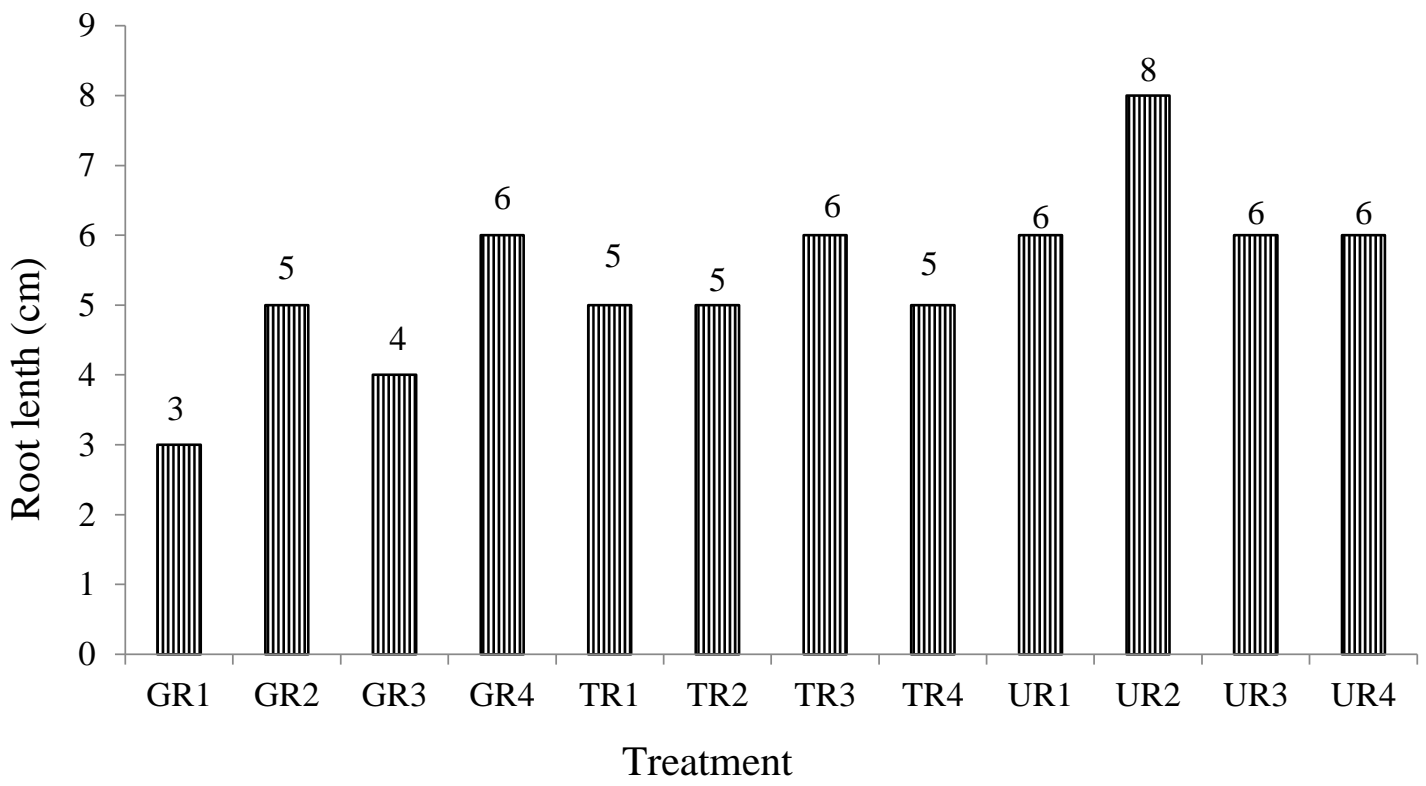

Figure 3: Effect of industrial effluent and groundwater on growth of root length

The root length of plant was increased for the irrigation of treated, untreated industrial effluents and groundwater. At 45 days the maximum root length $(8 \mathrm{~cm})$ was recorded in $\mathrm{UR}_{4}$ treatment and minimum root length $\left(3 \mathrm{~cm}\right.$ ) was observed from $\mathrm{GR}_{1}$ (Figure 3 ). Mohiuddin et al. (2016) observed the average root length of red spinach plant irrigated with polluted river water was $3.6 \mathrm{~cm}$ but $4.72 \mathrm{~cm}$ was in control treatment. Green weight of red spinach plant was varied for the irrigation of treated, untreated industrial effluents and groundwater at 25 and 45 DAS. At 25 DAS, the maximum green 
weight of plant $(4.5 \mathrm{~g})$ was obtained from $\mathrm{UR}_{3}$. On the other hand, the minimum green weight of plant $\left(3 \mathrm{~g}\right.$ ) was found from $\mathrm{GR}_{4}$. At 45 DAS the maximum green weight of plant $(8.5 \mathrm{~g})$ was obtained from $\mathrm{UR}_{2}$ and the minimum green weight of plant ( $4.2 \mathrm{~g}$ ) was found from $\mathrm{GR}_{1}$ (Figure 4). Mohiuddin et al. (2016) observed fresh weight of red spinach plant irrigated with polluted river water ranged from 5.6 to $18.4 \mathrm{~g}$ with an average of 10.11 and $12.2 \mathrm{~g}$ in control condition. Naz, Anjum and Akhtar (2016) recorded total fresh weight of leaves per spinach plant irrigated with canal, tube well and sewage water were $143.67,137.10$ and $165.57 \mathrm{~g}$, respectively.

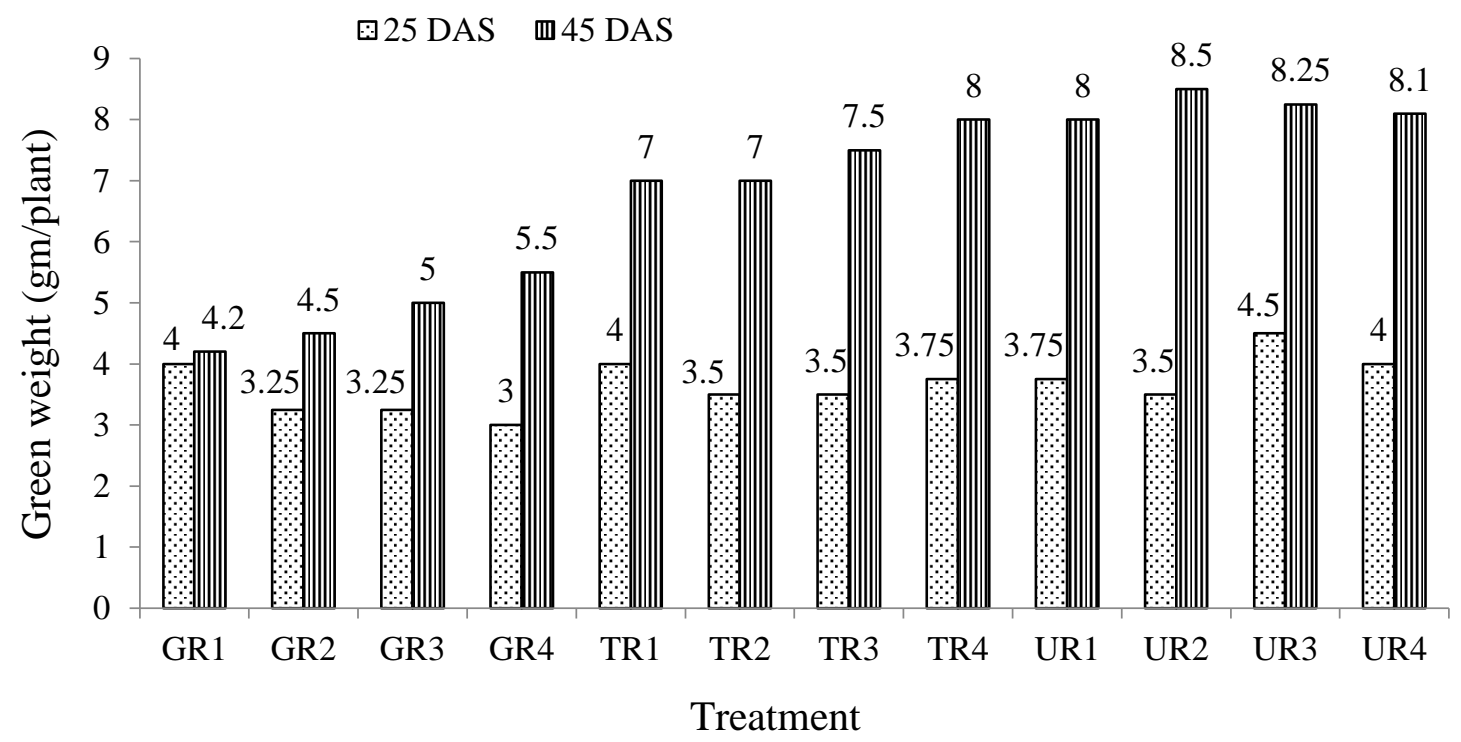

Figure 4: Effect of industrial effluent and ground water on the green weight of red spinach plant

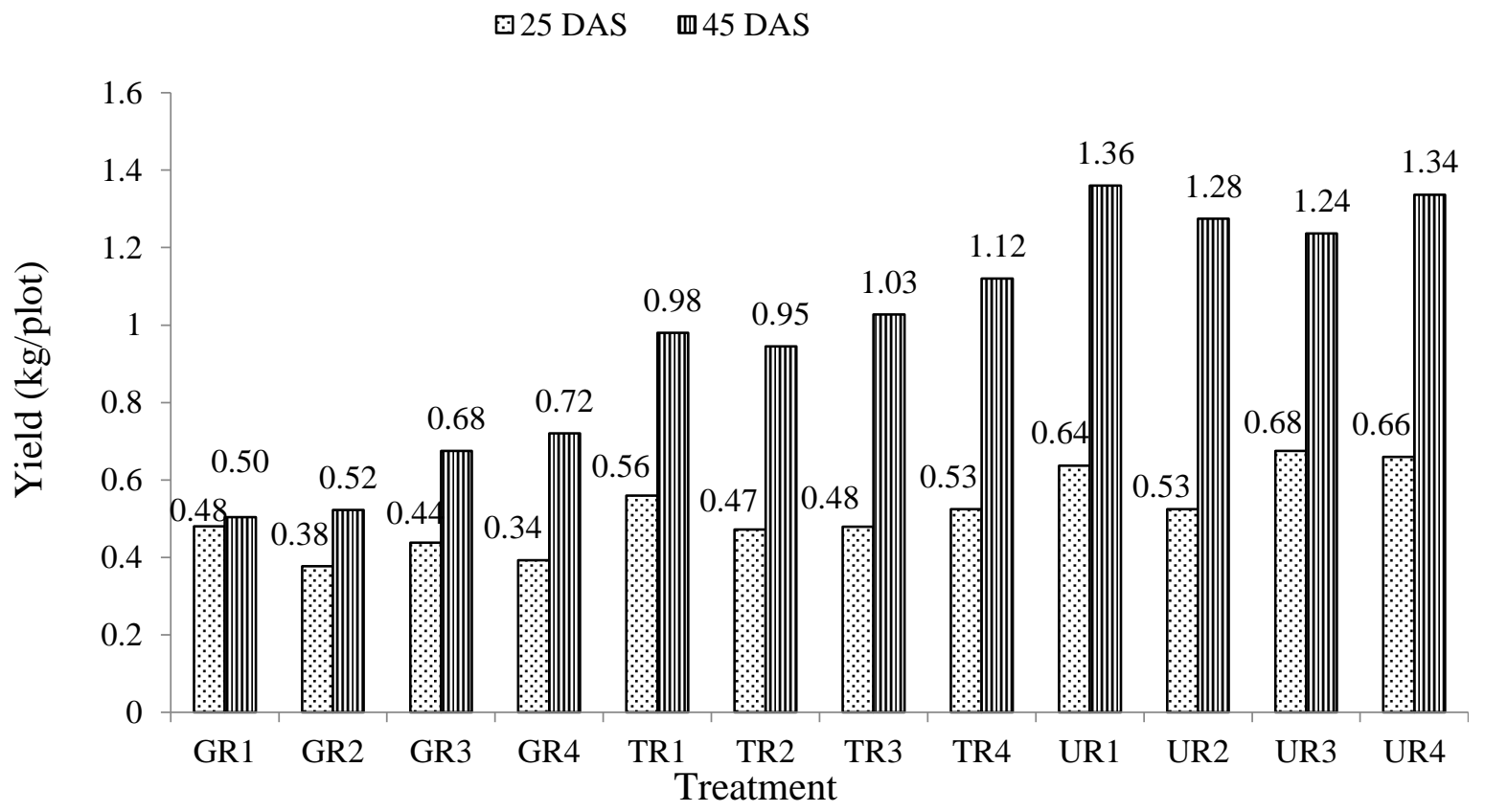

Figure 5: Effect of industrial effluent and groundwater on yield per plot of red spinach 
Significant variation was recorded in terms of yield per plot of red spinach due to irrigation of treated, untreated industrial effluents and groundwater at 25 and 45 DAS. At 25 and 45 DAS, the nicest yield per plot $\left(0.675\right.$ and $1.36 \mathrm{~kg}$ ) was obtained from $\mathrm{UR}_{3}$ and $\mathrm{UR}_{1}$, respectively. On the other hand, the lowest yield per plot $(0.377$ and $0.504 \mathrm{~kg})$ was recorded from $\mathrm{GR}_{2}$ and $\mathrm{GR}_{1}$ (Figure 5). It was observed that with the increase of irrigation with untreated industrial effluents, vegetative growth of red spinach also increased that ensured the highest yield per plot. Mohiuddin et al. (2016) observed the maximum no. of plant (58.0) was observed in pot where normal water was used for irrigation.

Table 2: Effect of industrial effluent and groundwater on yield per hectare, dry weight of red spinach plant, moisture content and dry matter content of red spinach plant

\begin{tabular}{|c|c|c|c|c|c|c|c|c|c|}
\hline \multirow{3}{*}{$\begin{array}{l}\text { Water/ } \\
\text { effluent }\end{array}$} & \multirow{3}{*}{ Treatment } & \multicolumn{2}{|c|}{$\begin{array}{c}\text { Yield per } \\
\text { hectare (ton) }\end{array}$} & \multicolumn{2}{|c|}{$\begin{array}{c}\text { Dry weight } \\
\text { (gm/plant) }\end{array}$} & \multicolumn{2}{|c|}{$\begin{array}{c}\text { Moisture } \\
\text { content }(\%)\end{array}$} & \multicolumn{2}{|c|}{$\begin{array}{c}\text { Dry matter } \\
\text { content }(\%)\end{array}$} \\
\hline & & 25 & 45 & 25 & 45 & 25 & 45 & 25 & 45 \\
\hline & & DAS & DAS & DAS & DAS & DAS & DAS & DAS & DAS \\
\hline \multirow{4}{*}{$\begin{array}{l}\text { Ground } \\
\text { water }\end{array}$} & $\mathrm{GR}_{1}$ & 0.831 & 0.872 & 0.85 & 0.95 & 78.75 & 77.38 & 21.25 & 22.62 \\
\hline & $\mathrm{GR}_{2}$ & 0.653 & 0.903 & 0.75 & 0.92 & 76.92 & 79.56 & 23.08 & 20.44 \\
\hline & $\mathrm{GR}_{3}$ & 0.758 & 1.169 & 0.75 & 1.10 & 76.92 & 78.00 & 23.08 & 22.00 \\
\hline & $\mathrm{GR}_{4}$ & 0.681 & 1.247 & 0.72 & 1.20 & 75.00 & 78.18 & 25.00 & 21.82 \\
\hline \multirow{4}{*}{$\begin{array}{l}\text { Treated } \\
\text { effluent }\end{array}$} & $\mathrm{TR}_{1}$ & 0.970 & 1.697 & 0.85 & 1.20 & 78.75 & 78.18 & 21.25 & 21.82 \\
\hline & $\mathrm{TR}_{2}$ & 0.817 & 1.636 & 0.80 & 1.50 & 77.14 & 78.57 & 22.86 & 23.43 \\
\hline & $\mathrm{TR}_{3}$ & 0.829 & 2.208 & 0.80 & 1.50 & 77.14 & 78.57 & 22.86 & 23.43 \\
\hline & $\mathrm{TR}_{4}$ & 0.909 & 2.078 & 0.92 & 1.50 & 75.47 & 78.57 & 22.53 & 23.43 \\
\hline \multirow{4}{*}{$\begin{array}{l}\text { Untreated } \\
\text { effluent }\end{array}$} & $\mathrm{UR}_{1}$ & 1.103 & 2.355 & 0.92 & 1.60 & 75.47 & 80.00 & 22.53 & 20.00 \\
\hline & $\mathrm{UR}_{2}$ & 0.909 & 2.142 & 0.83 & 1.60 & 77.14 & 80.00 & 22.86 & 20.00 \\
\hline & $\mathrm{UR}_{3}$ & 1.169 & 2.142 & 1.10 & 1.62 & 75.56 & 80.94 & 24.44 & 19.06 \\
\hline & $\mathrm{UR}_{4}$ & 1.143 & 2.315 & 0.95 & 1.62 & 76.25 & 80.94 & 23.75 & 19.06 \\
\hline
\end{tabular}

Note: $\mathrm{GR}_{1}, \mathrm{GR}_{2}, \mathrm{GR}_{3}, \mathrm{GR}_{4}$ indicate four plots irrigated with ground water, $\mathrm{TR}_{1}, \mathrm{TR}_{2}, \mathrm{TR}_{3}, \mathrm{TR}_{4}$ indicate four plots irrigated with industrial treated effluents, and $\mathrm{UR}_{1}, \mathrm{UR}_{2}, \mathrm{UR}_{3}, \mathrm{UR}_{4}$ indicate four plots irrigated with industrial untreated effluents, DAS = days after sowing.

Variation in terms of yield per hectare of red spinach was recorded. At 25 and 45 DAS, the highest yield per hectare (1.169 and 2.355 ton) was obtained from $\mathrm{UR}_{3}$ and $\mathrm{UR}_{1}$ treatment, respectively (Table 2). On the other hand, at 25 and 45 DAS the lowest yield per hectare $(0.653$ ton and 0.872 ton) was recorded from $\mathrm{GR}_{2}$ and $\mathrm{GR}_{1}$ treatment, respectively. It was revealed that with the increase of untreated effluents on vegetative growth of red spinach also increased that ensured the highest yield per hectare. Naz, Anjum and Akhtar (2016) found yield per hectare for spinach plant irrigated with canal, tube well and sewage water were 66.58, 63.64 and $77.73 \mathrm{t} / \mathrm{ha}$. Dry weight of red spinach plant showed significant variation due to irrigation by treated, untreated industrial effluents and groundwater at 25 and 45 DAS. At 25 DAS, the maximum dry weight of plant $(1.1 \mathrm{~g})$ was obtained from $\mathrm{UR}_{3}$ and the minimum dry weight of plant $(0.72 \mathrm{~g})$ was found from $\mathrm{GR}_{4}$. On the other hand, at $45 \mathrm{DAS}$, the maximum dry weight of plant $(1.62 \mathrm{~g})$ was obtained from $\mathrm{UR}_{3}$ and $\mathrm{GR}_{2}$ and the minimum dry weight of plant $(0.92 \mathrm{~g})$ was found from $\mathrm{GR}_{2}$. Mohiuddin et al. (2016) observed dry weight of red spinach plant irrigated with polluted river water ranged from 0.54 to $1.50 \mathrm{~g}$ with an average of $1.01 \mathrm{~g}$, respectively and $1.50 \mathrm{~g}$ in control condition. Naz, Anjum and Akhtar (2016) 
Doi: https://doi.org/10.33002/nr2581.6853.02043

recorded total dry weight of leaves per spinach plant irrigated with canal, tube well and sewage water were $11.49,10.96$ and $13.24 \mathrm{~g}$, respectively.

At 25 DAS, the maximum moisture content of red spinach plant $(78.75 \%)$ was obtained from $\mathrm{GR}_{1}$ and $\mathrm{TR}_{1}$. On the other hand, the minimum moisture content of plant $(75.00 \%)$ was found from $\mathrm{GR}_{4}$. At 45 DAS the maximum green weight of plant $(80.94 \%)$ was obtained from $\mathrm{UR}_{3}$ and $\mathrm{UR}_{4}$ and the minimum moisture content of plant $\left(77.38 \%\right.$ ) was found from $\mathrm{GR}_{1}$. Dry matter content was also determined in red spinach plant by using the formula: \% Dry matter content $=100$ - Moisture content. Highest dry matter content was found at $\mathrm{UR}_{3}(24.44)$ and $\mathrm{TR}_{2}, \mathrm{TR}_{3}, \mathrm{TR}_{4}$ (23.43) at $25 \mathrm{DAS}$ and 45 DAS, respectively. Lowest was found from $\mathrm{TR}_{1}, \mathrm{GR}_{1}(21.25)$ in $25 \mathrm{DAS}$ and $\mathrm{UR}_{3}, \mathrm{UR}_{4}$ (19.06) at 45 DAS, respectively.

The correlation between two variables is much more important to know the significant relationship between them. Table 3 showed the correlation matrix of different parameter of red spinach plant, which showed positive correlation between the leaves length and number of leaves per plant $(\mathrm{r}=$ $\left.0.680^{*}\right)$, leaves length and yield per plot $\left(\mathrm{r}=0.811^{* *}\right)$, number of leaves per plot and yield per plot $\left(\mathrm{r}=0.596^{*}\right)$, leaves breadth and yield per plot $\left(\mathrm{r}=0.781^{* *}\right)$, leaves breadth and yield per plot $(\mathrm{r}=$ $\left.0.934^{* *}\right)$, base diameter and yield per plot $\left(\mathrm{r}=0.611^{*}\right)$, number of plants per plot and yield per plot $(\mathrm{r}=0.924 * *)$, number of plants per plot and leaves length of red spinach plant $(\mathrm{r}=0.834 * *)$, number of plants per plot and leaves breadth of red spinach $\left(\mathrm{r}=0.775^{* *}\right)$, number of leaves per plants and base diameter of red spinach $(r=0.204)$, fresh weights and number of plants per plot $(r$ $\left.=0.811^{* *}\right)$.

Table 3: Correlation coefficient among different parameters of red spinach plant

\begin{tabular}{|l|c|c|c|c|c|c|c|}
\hline Parameters & $\begin{array}{c}\text { Leaves } \\
\text { length }\end{array}$ & $\begin{array}{c}\text { No. of } \\
\text { leaves }\end{array}$ & $\begin{array}{c}\text { Leaves } \\
\text { breadth }\end{array}$ & $\begin{array}{c}\text { No. of } \\
\text { plants }\end{array}$ & $\begin{array}{c}\text { Base } \\
\text { diameter }\end{array}$ & $\begin{array}{c}\text { Fresh } \\
\text { weight }\end{array}$ & $\begin{array}{c}\text { Yield } \\
\text { per plot }\end{array}$ \\
\hline Leaves length & 1 & & & & & & \\
\hline No. of leaves & $0.680^{*}$ & 1 & & & & & \\
\hline Leaves & $0.781^{*}$ & 0.769 & 1 & & & & \\
\hline No. of plants & 0.832 & 0.451 & $0.775^{* *}$ & 1 & 1 & 1 & \\
\hline Base diameter & 0.521 & 0.204 & 0.449 & 0.564 & 1 & \\
\hline Fresh weight & 0.715 & 0.605 & 0.957 & $0.811^{* *}$ & 0.600 & 1 \\
\hline Yield per plot & 0.811 & $0.596^{*}$ & $0.934^{* *}$ & $0.924^{* *}$ & $0.611^{* *}$ & $0.971^{* *}$ & 1 \\
\hline
\end{tabular}

$* *$ Correlation is significant at the 0.01 level (2-tailed), * Correlation is significant at the 0.05 level (2-tailed)

Heavy metal $(\mathrm{Cu}, \mathrm{Cd}$ and $\mathrm{Zn})$ were analyzed in soil, water and plant samples. Initial soil samples were collected and analyzed before seed sowing and irrigation. Other soil samples were collected and analyzed after red spinach harvesting at 45 DAS. The concentration of $\mathrm{Zn}$ in soil was ranged from 136.55 to $210.07 \mathrm{ppm}$ (Table 4). The highest content of $\mathrm{Zn}$ (210.07 ppm) was found at soil irrigated with untreated effluent and lowest content $(136.55 \mathrm{ppm})$ was found at initial soil. Content of $\mathrm{Cd}$ in soil was found to vary from 0.77 to $1.03 \mathrm{ppm}$. The highest content of $\mathrm{Cd}(1.03 \mathrm{ppm})$ was found at soil irrigated with untreated effluent and lowest concentration $(0.77 \mathrm{ppm})$ was found at initial soil. The range of $\mathrm{Cu}$ content varies from 47.32 to $73.58 \mathrm{ppm}$. The highest content of $\mathrm{Cu}$ $(73.58 \mathrm{ppm})$ was found at soil irrigated with untreated effluent and lowest concentration (47.32 ppm) was found at initial soil (Table 4). Bedbabisa et al. (2010) detected heavy metals 
concentrations in soil irrigated with well water ranged between 25 to $27.3 \mathrm{ppm}$ for $\mathrm{Zn}$ and $<0.004$ ppm for $\mathrm{Cd}$, and in soil irrigated with treated wastewater were ranged between 28 and $33.5 \mathrm{ppm}$ for $\mathrm{Zn}$ and $<0.004 \mathrm{ppm}$ for Cd. Singh, Sharma and Agarwal (2008) observed concentration of Zn, $\mathrm{Cd}$ and $\mathrm{Cu}$ 13.45, 0.30 and $8.80 \mathrm{ppm}$ in initial soil.

Table 4: Heavy metals concentrations in soil at different plot of the study

\begin{tabular}{lccc}
\hline \multirow{2}{*}{ Soil samples } & \multicolumn{3}{c}{ Heavy metals $(\mathrm{ppm})$} \\
\cline { 2 - 4 } & $\mathrm{Zn}$ & $\mathrm{Cd}$ & $\mathrm{Cu}$ \\
\hline Initial soil (control) & 136.55 & 0.77 & 47.32 \\
Soil with treated effluent & 193.28 & 0.93 & 57.29 \\
Soil with untreated effluent & 210.07 & 1.03 & 73.58 \\
Soil with groundwater & 182.83 & 0.85 & 48.93 \\
\hline
\end{tabular}

Heavy metals were also observed in water/effluent used for irrigation purposes. The highest content of $\mathrm{Zn}, \mathrm{Cd}$ was $0.070,0.011$ and $0.680 \mathrm{ppm}$, respectively found in untreated industrial effluents, and the lowest content of $\mathrm{Cd} 0.004 \mathrm{ppm}$ found in ground water. $\mathrm{Zn}$ content was absent in ground water and treated effluent whereas $\mathrm{Cu}$ was also absent in groundwater. The observed concentrations of $\mathrm{Zn}, \mathrm{Cd}$ and $\mathrm{Cu}$ in water/ effluent were within the standard level (Table 5). Mohiuddin et al. (2016) recorded in water samples collected from different sites of the river around the Dhaka city, the mean concentration of $\mathrm{Zn}$ was $0.399 \mathrm{ppm}, \mathrm{Cu}$ was $0.2 \mathrm{ppm}$ and the level of $\mathrm{Cd}$ found below detectable limit. Roy and Gupta (2016) observed mean concentrations of $\mathrm{Zn}, \mathrm{Cd}$ and $\mathrm{Cu}$ of well water and wastewater used as irrigation water were 1.07, 0.05 and $0.04 \mathrm{ppm}$.

Table 5: Heavy metals concentrations in groundwater, treated and untreated effluents of the study with their standard

\begin{tabular}{ccccc}
\hline \multirow{2}{*}{$\begin{array}{c}\text { Heavy metals } \\
(\mathrm{ppm})\end{array}$} & \multicolumn{3}{c}{ Water used for irrigation } & ADB (1994) standard \\
\cline { 2 - 4 } & Groundwater & Treated effluent & $\begin{array}{c}\text { Untreated } \\
\text { effluent }\end{array}$ & \\
\hline $\mathrm{Zn}$ & 0.000 & 0.000 & 0.070 & 5.00 \\
$\mathrm{Cd}$ & 0.004 & 0.006 & 0.011 & 0.01 \\
$\mathrm{Cu}$ & 0.000 & 0.020 & 0.680 & 0.20 \\
\hline
\end{tabular}

Table 6: Heavy metals concentrations in red spinach (Amaranthus dubius) irrigated with different water sources

\begin{tabular}{ccccc}
\hline \multirow{2}{*}{$\begin{array}{c}\text { Heavy metals } \\
(\mathrm{ppm})\end{array}$} & Groundwater & Treated effluent & Untreated effluent & $\begin{array}{c}\text { *WHO/ FAO } \\
\text { (1989) standard } \\
(\mathrm{ppm})\end{array}$ \\
\cline { 2 - 4 } $\mathrm{Zn}$ & 61.64 & 65.30 & 67.67 & 99.40 \\
$\mathrm{Cd}$ & 0.33 & 0.52 & 0.57 & 0.20 \\
$\mathrm{Cu}$ & 5.73 & 7.79 & 7.95 & 73.30 \\
\hline
\end{tabular}

*WHO/FAO (1989) guidelines for heavy metals concentration in leafy vegetables.

The range of $\mathrm{Zn}, \mathrm{Cd}$ and $\mathrm{Cu}$ contents varied from 61.64 to $67.67,0.33$ to 0.57 and 5.73 to 7.95 $\mathrm{ppm}$, respectively in red spinach at different plot. The highest content of $\mathrm{Zn}, \mathrm{Cd}$ and $\mathrm{Cu}$ were observed in red spinach plant irrigated with untreated effluent and their lowest content observed in 
red spinach plant irrigated with ground water. The observed $\mathrm{Zn}$ and $\mathrm{Cd}$ contents in red spinach were within the permissible limit given by WHO/FAO (1989) but the concentration of Cu exceeded the permissible level (Table 6). Bedbabisa et al. (2010) found heavy metals concentrations in Olive leaves between 15.92 and $15.22 \mathrm{ppm}$ for $\mathrm{Zn}$, and $<0.004 \mathrm{ppm}$ for $\mathrm{Cd}$ in well water treatment; between 18.58 and $19.04 \mathrm{ppm}$ for $\mathrm{Zn}$, and $<0.004 \mathrm{ppm}$ for $\mathrm{Cd}$ in treated wastewater treatment.

\section{Conclusion}

From the overall discussion of the study, it could be concluded that the physical properties of red spinach (Amaranthus dubius) and heavy metal concentrations in soil and water were influenced by the industrial effluents especially untreated one. The study should be conducted in farmer's field to observe the actual response and more combination of treatment should be applied for more accuracy in near future. Appropriate legislation for enhancing the performance of regulatory agencies should be provided and a technical committee should also be established in order to reduce the discharge of industrial effluents into the river and canal including any kind of water bodies without treatment. Irrigation by industrial effluents in agricultural purposes should be stopped and there should be made extensive awareness campaign on the adverse effect of heavy metal accumulation in vegetables among farmers of grass root level in Bangladesh and the globe.

\section{Acknowledgement}

Sincere appreciation to the University Grants Commission (UGC) of Bangladesh for financial support through the Research Cell of the Mawlana Bhashani Science and Technology University to carry out the research smoothly and successfully.

\section{References}

ADB (Asian Development Bank) (1994). Training manual for environmental monitoring. Engineering Science Inc., USA. 2-16 pp.

Alloway, J.B. (1995). Soil pollution and land contamination. In: Harrison, R.M. (Ed). Pollution: causes, effects and control. The Royal Society of Chemistry, Cambridge: Cambridge University Press.

Arjun, S.K., Kumar, S., Kumar, Y. and Sharma, H.C. (2013). Effect of fertilizer factory effluent on wheat crop: a case study. Access International Journal, 1(7): 81-90.

Bahadir, T., Bakan, G., Altas, L. and Buyukgungor, H. (2007). The investigation of lead removal by biosorption: an application at storage battery industry wastewater. Enzyme and Microbial Technology, 41: 98-102.

Bedbabisa, S., Ferrarab, G., Rouinac, B.B. and Boukhrisa, M. (2010). Effects of irrigation with treated wastewater on olive tree growth, yield and leaf mineral elements at short term. Scientia Horticulturae, 126: 345-350.

Diskshith, T.S.S. and Diwan, P.V. (2003). Industrial guide to chemical and drug safety. New York, USA: Wiley.

Fernandes, J.C. and F.S. Henriques (1991). Biochemical, physiological and structural effects of excess copper in plants. The Botanical Review, 57: 246-273.

Fisher, N.S., Jones, G.J. and Nelson, D.M. (1981). Effect of copper and zinc on growth, morphology and metabolism of Asterionella japonica (Cleve). Journal of Experimental Marine Biology and Ecology, 51: 37-56. 
Komarek, M., Tlustos, P., Szakova, J. and Chrastny, V. (2008). The use of poplar during a two year induced phytoextraction of metals from contaminated agricultural soils. Environmental Pollution, 151: 27-38.

Mohiuddin, K.M., Alam, M.M., Rahman, M.S., Islam, M.S. and Ahmed, I. (2016). Effect of polluted river water on growth, yield and heavy metal accumulation of red amaranth. Research in Agriculture, Livestock and Fisheries, 3 (1): 53-65.

Nandy, T. and S.N. Kaul (1994). Wastewater management for tapioca-based sago industry. Indian Journal of Environmental Protection, 14: 721-728.

Naz, S., Anjum, M.A. and S. Akhtar (2016). Monitoring of growth, yield, biomass and heavy metals accumulation in spinach grown under different irrigation sources. International Journal of Agriculture and Biology, 18: 689-697.

Pagotto, C., Rèmy, N., Legret, M. and Cloirec, P.L. (2001). Heavy metal pollution on road dust and roadside soil near a major rural highway. Environmental Technology, 22: 307-319.

Roy, S. and Gupta, S. (2016). Effect of wastewater irrigation on soil and some selected vegetables grown in Asansol, West Bengal. International Journal of Environmental Sciences, 6(5): 894904.

Singh, A., Sharma, R.K. and Agarwal, S.B. (2008). Effects of fly ash incorporation on heavy metal accumulation, growth and yield responses of Beta vulgaris plants. Bioresource Technology, 99: 7200-7207.

Singh, K.P. and Singh, K. (1981). Stress physiological studies on seed germination and seedling growth of source wheat hybrids. Indian Journal of Physiology and Pharmacology, 24: 180186.

WHO/FAO (World Health Organization/ Food and Agriculture Organization) (1989). Report of $33^{\text {rd }}$ meeting of joint $\mathrm{WHO} / \mathrm{FAO}$ expects committee on foods additives. Toxicological evaluation of certain foods additives and contaminants \# 24, International program on chemical safety, WHO, Geneva. 